\title{
DIFFERENCES IN THE CONCEPT OF RISK MANAGEMENT IN V4 COUNTRIES
}

\author{
Zuzana Virglerova \\ Tomas Bata University in Zlín \\ Zlin, Czech Republic \\ virglerova@utb.cz
}

\begin{abstract}
Risk management is one of the entrepreneurial knowledge to reduce business risks. The aim of the article is to compare the access to risk management in SMEs in the Visegrad countries (V4). The attention is focused on the differences in a perception of the importance of various risks, the choice of the person responsible for risk management and the frequency of discussion on the current risks in the company. The article deals with the partial results of the empirical questionnaire survey which was completed in 2018 at the Tomas Bata University in Zlin in the Czech Republic. The survey was made among SMEs in the Czech Republic (408 respondents), Slovakia (487), Poland (489) and Hungary (388). The questionnaire included questions about the importance of risks and the concept of risk management in the company. Three research questions were set. To test the formulated research questions, the following statistical tools, such as pivot table, relative and absolute frequency, the Chi-Square calculator for 5 x 5 Contingency Table and Z-score, were used. Finally, the result indicates a different perception of the key risks in Hungary (in comparison with other V4 countries). There are also statistically significant differences in the frequency of discussion on the current risks in relation to the size of the company among V4 countries. The differences among the companies from V4 countries in the choice of the person responsible for risk management were proved as well. The article concludes with a discussion on the comparison of the previous international researches.
\end{abstract}

KEYWORDS: risk management, V4 countries, risk manager, SMEs

JEL CLASSIFICATION: D81, G32, M21

DOI: $10.2478 /$ IJEK-2018-0017

Received: $21^{\text {st }}$ October, 2018.

1st Revision: $23^{\text {rd }}$ November, 2018.

Accepted: $27^{\text {th }}$ November, 2018.

Reference: Virglerová, Z. (2018). Differences in the Concept of Risk Management in V4 Countries. International Journal of Entrepreneurial Knowledge, 6(2), 100-109. doi: 10.2478/IJEK-2018-0017

\section{INTRODUCTION}

Business risks are parts of the business environment which all enterprises must confront every day. Business environment shows the quality of the business conditions and condition for own economic activities as well. If the business environment has high-quality conditions, the sustainable economic growth and business development of enterprises can improve their competitiveness in the international comparison. (Belanová, K., 2014, Ključnikov \& Junger, 2013, Cepel et al, 2018).

The business environment is determined also by the motives of individual entrepreneurs and their personal characteristics. Business situations and conditions for decisions are often unpredictable and they are changing during the whole decision-making process. There is no manual which can be used in each situation. (Kozubíková et al., 2015). Therefore, the risk management and risk assessment should be in the interest of each manager of the enterprise.

Especially small and medium enterprises must be aware of all factors of the business environment, because every negligence can have some fatal consequences. Čunderlík \& Rybárová (2002) state that 
the SME activity is connected to many risks, such as operational, personnel, market, security, production and financial risks. It is very important to evaluate all possible risks and realize risks during all decisions are made by company. In fact, every decision poses a risk to a company. For example, Kramoliš (2014) stated that the companies in the Czech Republic try to decrease the risk of market failure by using a marketing during the whole product lifecycle.

Business risks are very complex and include several types of risks in the whole business. Fetisovova et al. (2012) introduced a complex approach to business risks and divide them into five categories, including strategic risks, operational risks, financial risks, social-political risks and reputation risks.

This paper examines the differences in the concept of risk management in SMEs in V4 countries (Czech Republic, Slovakia, Poland, Hungary). Three aspects were analysed: the importance given to the various risks, the difference in the person responsible for a risk management and the frequency of discussion on the current risks inside the enterprises.

The structure of the paper is as follows: In the theoretical part, the importance of risk management as a part of the business environment is presented. Three research questions were set. It is introduced the empirical research of the risk management in the Czech Republic, Slovakia, Poland and Hungary and the Chi-Square calculator for 5 × 5 Contingency Table and Z-score ( $\mathrm{p}$-value with 0,05 level of significance) are applicated. At the end of this paper, the main results of the research are stated.

\section{THEORETICAL BASES}

Globalization has a huge impact on entrepreneurs, especially on SMEs. Economic turbulence in the business world increases uncertainty and risk, which increases the pressure on businesses and small and medium enterprises (Hussain et al., 2015). This research was focused on small and medium enterprises as an important part of the world economy (Henderson \& Weiler, 2010).

The business environment consists of internal and external factors that have effects on company functions (including management, supply and demand, employees and business regulations). Every business operation is confronted with several risks. The European risk and insurance report (2016) presents TOP 10 risks in companies worldwide as follows:

1. Interest rate and foreign exchange

2. Business continuity disruption

3. Reputation and brand

4. Non-compliance with regulation and legislation

5. IT systems and data centres

6. Economic condition

7. Cyber-attack/data privacy

8. Competition

9. Marketing strategy, clients

10. Political, country instability

The previous research of the business environment in the Czech Republic has shown that the most significant business risk in the SME segment evaluated by Czech and Slovak entrepreneurs is a market risk, which led to a significant change in the performance of the studied companies. At the same time, the study has revealed a high degree of confidence of individual groups of entrepreneurs when evaluating their ability to manage financial risks in the company. The transfer of financial risk to the suppliers by means of establishing contractual prices and conditions of fines in the case of contract conditions violation is very often. (Kozubíková et al., 2015; Taraba et al, 2015) Small and mediumsized enterprises are more vulnerable to the market environment perspective in comparison with big 
enterprises. The intensity of market risk as one of the biggest risks for SMEs confirmed many authors (e.g. Kot, 2018; Popp et al., 2018; Oláh et al., 2018). They define market risk as a loss of customers, strong competition in the industry, market stagnation and supplier misbehaviour.

During the crisis' periods, a negative impact of various risks is multiplied. (Christensen et al., 2015). The crisis also affects efficiency as well as the productivity and the income growth of countries and individual firms. The last financial crisis has changed the European SME managers view on risk management significantly. Some mistakes that had been done, such as a poor cash flow management or an insufficient financial risks management, were showed during the crisis. If managers enforced these mistakes, they could have reduced the negative influences of a crisis on their enterprises. (Krištofík, 2010). After negative experiences, risk management is becoming a much more important tool compared to the past. Risk management can be assumed as a comprehensive system of risk assessment and its application with an objective to minimize threats and maximize opportunities. (De Oliveira et al., 2017). The research results made by Federation of European Risk Management Associations showed evidence of the increased need for informing the top management about the state of risk management, increased interest in a top risk manager at the top management level, increased interest in the risks which gradually get into the process of the management decisions. (European Risk an Insurance Report, 2016)

Based on the worldwide surveys, e.g. Global State of Enterprise Risk Oversight (2015), it is possible to assess that there are still some shortcomings in terms of its application although there is the increasing interest in an implementation of risk management and the proven benefits of this implementation in the company. According to foreign studies, e.g. Report on the Current State of Enterprise Risk Oversight: Update on Trends and Opportunities (2015), only 25\% of managers believe that their company has an effective integrated approach to risk management. Global surveys show that even though the risk management of the company is not a new discipline, the current models of risk management are not flexible enough to be able to consider the dynamics of the market.

Publications in the field abroad have established the positive effects of risk management on the quality of decision-making processes, on increasing company value, on quality of the provided information, on securing the competitiveness, on achieving the process of sustainable improvement and on prevention in the framework of ensuring a continuous operation of the company (DeLoach, 2000; Urbancová \& Hudáková, 2015; Varcholová et al., 2008; Hopkin, 2013). According to the surveys made by several authors the importance of proper risk management was proven by e.g. Kral et al. (2015); Vodak et al. (2014); Urbancová et al. (2015). The application of risk management is less systematic in many enterprises as compared to developed countries and it is made with a certain reserve (Gavurova et al. 2017).

The choice of a person responsible for a risk management in the company is one of the key issues of setting risk management properly. This role can be entrusted to the person specialized for risk management (risk manager who is inside the company or outsourced from outside) or to the person in lower management (leader of some department, teams etc.). If the company does not discuss this role in the company, the entire responsibility stays on the owner of the company (or on the whole top management).

According to the European risk and insurance report (2016) are risk managers generally:

male $(73 \%$, compared to $27 \%$ female),

- between 36-55 years $(72 \%)$,

- earning more than 100000 EUR a year (46\%),

- $62 \%$ working for companies with turnover exceeding 1 billion EUR

- $80 \%$ working for companies with more than 20000 employees and dedicating four or more full-time employees to risk management. 
Many researchers confirmed that entrepreneurs with a university education perceive the intensity of factors linked to the business environment differently and have a better capability for managing the business and financial risks in the companies. (e.g. Belás et al., 2016; Ključnikov \& Sobekova Majková, 2016; Ključnikov \& Belás, 2016; Paulik et al., 2015).

Regardless of the choice of the person responsible for risk management, it is necessary to set the communication about risks within the company and reporting to the top management. Two-thirds of risk managers report to the board or top level ( $26 \%$ of them report to the chief financial officer). (European risk and insurance report, 2016).

\section{AIM AND METHODOLOGICAL BASES}

The aim of the article is to compare the access to risk management in SMEs from V4 countries. The attention was focused on the differences in a perception of the importance of various risks, the choice of the person responsible for risk management and the frequency of discussion on the current risk in the company.

The article uses a partial information from a huge international research which was organized by Tomas Bata University in Zlín. The research was focused on risk management, the analysis of the current situation of risk management in companies and the causes of deficiencies in the processes of risk management.

The following countries participated: Czech Republic (Tomas Bata University in Zlín), Slovakia (University of Žilina), Poland (Czestochowa University of Technology), Hungary (University of Debrecen), Serbia (University of Belgrade). The research was finished in 2018 and was carried out as follows: We obtained 408 responses of SMEs in the Czech Republic, 487 in Slovakia, 498 in Poland, 388 in Hungary, 329 in Serbia. Companies were chosen randomly from a database and were addressed directly by an e-mail to complete the questionnaire in an electronic form or in a paper form. This article is focused on a comparison of V4 countries, therefore, only these data were used.

The structure of the entrepreneurs' characteristics who filled in the questionnaire was as follows:

The Czech Republic (CR): men - 290 (71\%); women - 118 (29\%); according to age: up to 30 years - 68 (17\%); from 31 to 50 years - 107 (26\%); over 50 years - $233(57 \%)$.

Slovakia (SR): men - $325(67 \%)$; women - 162 (33\%); according to age: up to 30 years - $99(20 \%)$; from 31 to 50 years $-269(55 \%)$; over 50 years $-119(25 \%)$.

Poland (PL): men - $312(63 \%)$; women - $186(37 \%)$; according to age: up to 30 years - $111(22 \%)$; from 31 to 50 years $-285(57 \%)$; over 50 years $-102(20 \%)$.

Hungary (HU): men - $232(60 \%)$; women - $156(40 \%)$; according to age: up to 30 years - $158(41 \%)$; from 31 to 50 years $-170(44 \%)$; over 50 years $-60(15 \%)$.

To fulfil the main aim of the paper, the following research questions were formulated:

RQ1: There is no difference in a perception of the importance of various risks in SMEs inside V4 countries.

RQ2: There are significant differences in a choice of the person responsible for risk management among V4 countries.

RQ3: The size of the business is a significant factor for the frequency of discussion on the current risks in the company in all V4 countries.

The descriptive statistics tools (pivot table, relative and absolute frequency) in the first step were used. The Chi-Square calculator for 5 × 5 Contingency Table and Z-score were applied. The research questions were tested at the $5 \%$ level of statistical significance. The conditions for carrying out the $\mathrm{Z}$ test (normal distribution of samples according to the statistical features and the representativeness of the sample - a number of respondents) were fulfilled. The SPSS Statistics analytical software for data evaluation was used. 


\section{sciendo}

International Journal of Entrepreneurial Knowledge

\section{RESULTS}

For the first research question, direct responses of owners and managers from the companies were used. They were asked to identify a maximum of three risks from a selection of seven business risks which they consider to be the key in their business.

In the Czech Republic, from the total amount of 408, the share of key risks was as follows: $28 \%$ market risk, 20\% personnel risk, 18\% financial risk, 14\% economic risk, $8 \%$ operational risk, $5 \%$ legal risk, 5\% security risk and $1 \%$ other risks.

From the total amount of 487 SMEs addressed, the share of identified key risks of SMEs in Slovakia was identified as follows: market risks $31 \%$, economic risks $21 \%$, financial risks $18 \%$, personnel risks $10 \%$, operational risks $7 \%$, legal risks $6 \%$, security risks $5 \%$ and other risks $1 \%$.

The small and medium enterprises in Poland identified these key risks for their business: 35\% market risk, 22\% financial risk, 15\% economic risk, 13\% personnel risk, 5\% legal risk, 5\% security risk, 5\% operational risk, $1 \%$ other risks.

From the total amount of 388 SMEs addressed in Hungary, as key risks for their business were identified: $18 \%$ market risk, $16 \%$ financial risk, $15 \%$ economic risk, $13 \%$ operational risk, 13\% personnel risk, $10 \%$ legal risk, $9 \%$ security risk, $6 \%$ other risks.

The results can be seen in the figures below.

\section{Figure 1 The importance of risks in SMEs in V4 countries}

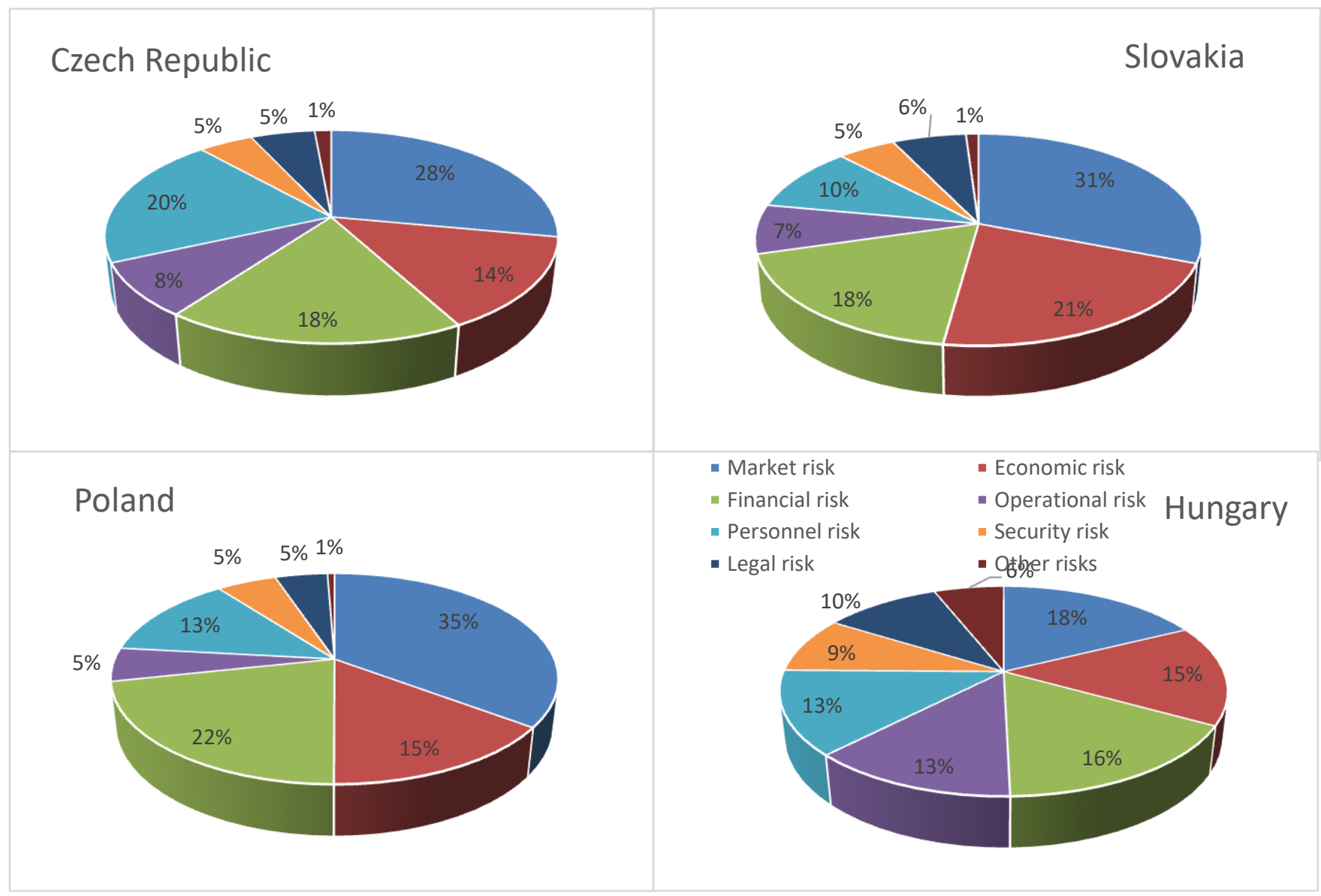


(Source: own)

The figure above shows that the perception of the importance of key risks in the Czech Republic, in Slovakia and in Poland is almost similar. The importance is given to the market risk, economic risk, financial risk and personnel risk. In Hungary is a different situation. All risks have a similar importance. It shows that in Hungary is a different perception of the importance of key risks. RQ1 was not confirmed.

The second research question was aimed at a person responsible for a risk management in the company and to the differences among countries as well. Fig. 2 shows an overview of the situation in companies in V4 countries. The situation is almost similar. The most common is a situation when the person responsible for a risk management is company owner (CR 69\%, SR 61\%, PL 70\%, HU 62\%). It can mean that the company has not discussed the risks in the company yet. Some of the small and medium companies state that there is nobody responsible for risk management (CR 12\%, SR 19\%, PL 14\%, HU $8 \%$ ). A manager authorized from the executive management is often used as a team leader of each department (CR 8\%/9\%, SR 8\%/8\%, PL 6\%,6\%, HU 13\%/10\%). A risk manager specialized in this activity is still a rare situation in V4 countries (CR 2\%, SR 4\%, PL 4\%, HU 6\%). Hungary with 6\% is a little bit further in the risk management concept in comparison with other V4 countries.

\section{Figure 2 An overview of a person responsible for risk management in SMEs in V4 countries}

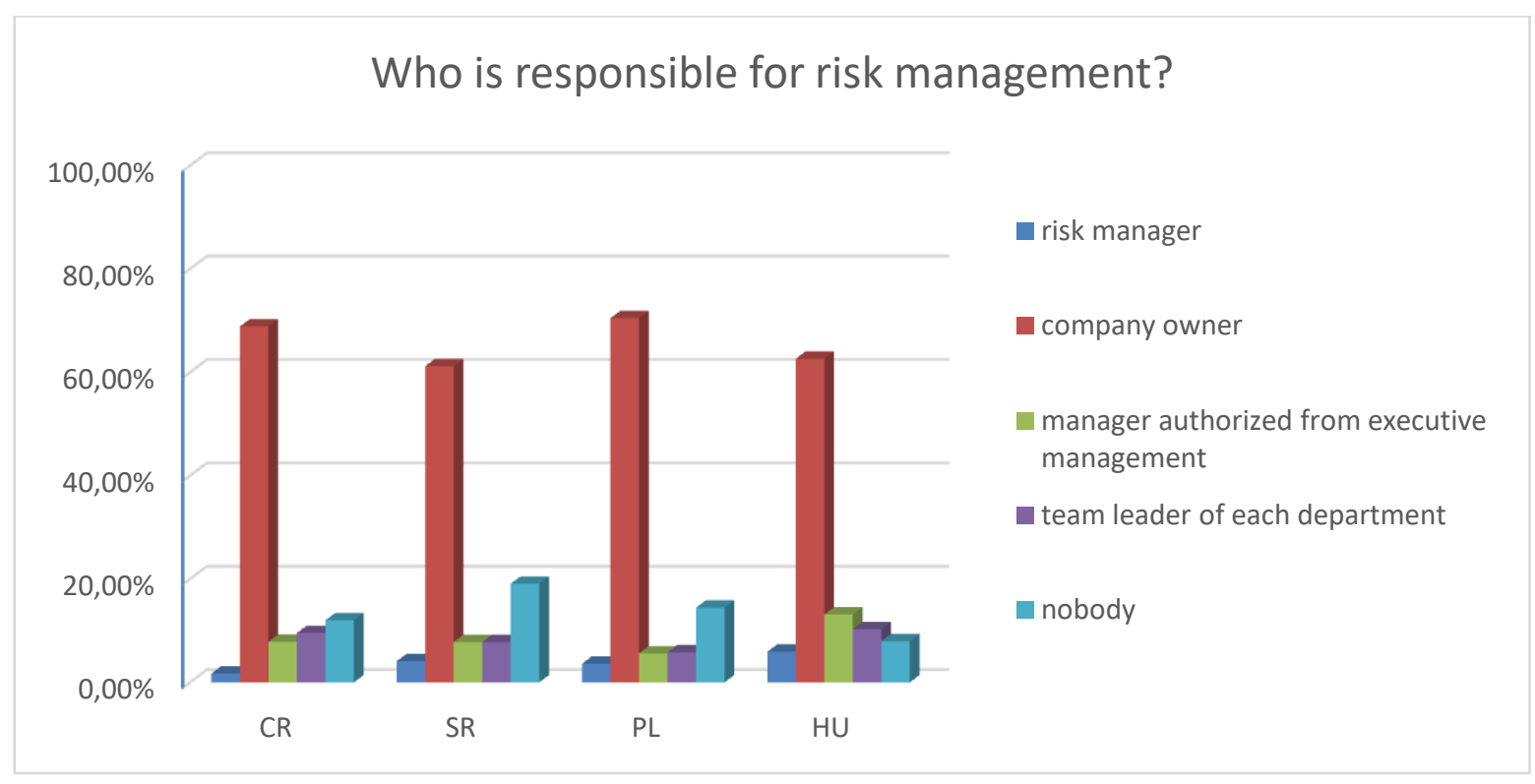

(Source: own)

An analysis of differences in the choice of the person responsible for risk management among V4 countries is presented in the table below.

Table 1 An analysis of the person responsible for risk management among V4 countries

\begin{tabular}{|l|r|r|r|r|r|r|r|}
\hline \multicolumn{6}{|c|}{ Who is responsible for risk management in your company? } & \multicolumn{3}{|c|}{ Z-score (p-value) } \\
\hline & CR & SR & PL & HU & CR/SR & CR/PL & CR/HU \\
& 7 & 20 & 18 & 23 & 0.0375 & 0.0819 & 0.0018 \\
\hline $\begin{array}{l}\text { Risk manager } \\
\text { Share in \% }\end{array}$ & $1.72 \%$ & $4.11 \%$ & $3.61 \%$ & $5.93 \%$ & & & \\
\hline
\end{tabular}




\begin{tabular}{|c|c|c|c|c|c|c|c|}
\hline & & & & & & & \\
\hline Company owner & 281 & 298 & 351 & 243 & 0.0168 & 0.6031 & 0.0629 \\
\hline Share in $\%$ & $68.87 \%$ & $61.19 \%$ & $70.48 \%$ & $62.63 \%$ & & & \\
\hline $\begin{array}{l}\text { Manager authorized from } \\
\text { executive management }\end{array}$ & 32 & 38 & 28 & 51 & 0.9840 & 0.1802 & 0.0143 \\
\hline Share in $\%$ & $7.84 \%$ & 7.80 & $5.62 \%$ & $13.14 \%$ & & & \\
\hline $\begin{array}{l}\text { Team leader of each } \\
\text { department }\end{array}$ & 39 & 38 & 29 & 40 & 0.3624 & 0.0340 & 0.7263 \\
\hline Share in $\%$ & $9.56 \%$ & $7.80 \%$ & $5.82 \%$ & $10.31 \%$ & & & \\
\hline Nobody & 49 & 93 & 72 & 31 & 0.0039 & 0.2801 & 0.0588 \\
\hline Share in $\%$ & $12.01 \%$ & $19.10 \%$ & $14.46 \%$ & $7.99 \%$ & & & \\
\hline $\begin{array}{l}\text { Chi-square } \\
\text { p-value }\end{array}$ & $\begin{array}{r}56.3069 \\
<0.00001 \\
\end{array}$ & & & & & & \\
\hline
\end{tabular}

(Source: own)

In the table above can be seen that there are statistically significant differences among the responses in V4 countries (chi-square 56.3069, p-value $=<0.00001$ ) at the $5 \%$ level of statistical significance. RQ2 was confirmed. When we look at the differences between the Czech Republic and other countries in a detail, we can see that significant differences are most often in relation to Slovakia (in responses: risk manager, owner and nobody). The Czech Republic and Hungary have statistically different responses in two cases - risk manager and manager authorized from executive management. The most similar is the Czech Republic and Poland - the statistical difference was confirmed only in the case of team leader of each department.

\section{Table 2 The frequency of discussion on key risks in SMEs in V4 countries}

\begin{tabular}{|c|c|c|c|c|c|c|c|c|c|}
\hline \multicolumn{10}{|c|}{$\begin{array}{l}\text { How often do you create the space for discussion on key risks in your } \\
\text { company? }\end{array}$} \\
\hline & $\begin{array}{l}\text { size of the } \\
\text { company }\end{array}$ & monthly & quarterly & $\begin{array}{l}\text { semi- } \\
\text { annually }\end{array}$ & yearly & $\begin{array}{l}\text { no } \\
\text { discussion }\end{array}$ & total & chi-square & $\mathrm{p}$-value \\
\hline \multirow[b]{3}{*}{ CR } & micro & 62 & 20 & 28 & 27 & 124 & 261 & \multirow{3}{*}{49.713} & \multirow{3}{*}{$<0,00001$} \\
\hline & small & 28 & 14 & 14 & 15 & 25 & 96 & & \\
\hline & medium & 24 & 14 & 3 & 6 & 4 & 51 & & \\
\hline \multirow[b]{3}{*}{ SR } & micro & 56 & 29 & 22 & 43 & 164 & 314 & \multirow{3}{*}{45.810} & \multirow{3}{*}{$<0,00001$} \\
\hline & small & 20 & 13 & 24 & 18 & 40 & 115 & & \\
\hline & medium & 21 & 10 & 10 & 8 & 9 & 58 & & \\
\hline \multirow[b]{3}{*}{ PL } & micro & 32 & 42 & 22 & 37 & 166 & 299 & \multirow{3}{*}{69.659} & \multirow{3}{*}{$<0,00001$} \\
\hline & small & 15 & 29 & 38 & 25 & 37 & 144 & & \\
\hline & medium & 14 & 13 & 8 & 10 & 10 & 55 & & \\
\hline \multirow[b]{3}{*}{$\mathrm{HU}$} & micro & 72 & 43 & 24 & 23 & 79 & 241 & \multirow{3}{*}{22.198} & \multirow{3}{*}{0,004563} \\
\hline & small & 26 & 17 & 13 & 6 & 10 & 72 & & \\
\hline & medium & 30 & 20 & 10 & 6 & 9 & 75 & & \\
\hline
\end{tabular}

(Source: own)

In the table above can be seen the frequency of discussion on key risks in SMEs in V4 countries in relation to the size of the company. The numbers mean the number of enterprises in each category. With a use of the Chi-Square calculator for $5 \times 5$ Contingency Table, the differences between the frequency of discussion and the size of the company were proven. The statistical differences were 
proven in SMEs in all V4 countries. In micro-companies in the Czech Republic, 48\% of enterprises do not discuss risks, in Slovakia $52 \%$, in Poland 56\% and in Hungary 33\%. It can be stated that in half of the micro-companies the risks are not discussed almost at all. Bigger companies have a discussion on risks more often than smaller companies. $74 \%$ of medium companies in the Czech Republic discuss the risks monthly (in Slovakia 36\%, in Poland 25\%, in Hungary 40\%). The differences among responses in relation to the size of the company are clear in all V4 countries. RQ3 was confirmed.

\section{DISCUSSION AND CONCLUSIONS}

The paper was focused on a comparison of access to risk management in SMEs which belong to V4 countries. The attention was focused on the differences in perception of the importance of various risks, the person responsible for risk management and the frequency of discussion on the current risk in the company. Three research questions were set to analyse the aim of the paper.

The first research question analysed a perception of the importance of key risks in SMEs within the Visegrad Group. It was confirmed that the most important risks for SMEs are market risk, financial risk and economic risk. This conclusion was confirmed by many other authors who have done similar researches (Belás et al., 2018; Kot, 2018; Popp et al., 2018; Oláh et al., 2018).

The market risk, financial risk and economic risk are perceived as most important only in SMEs in the Czech Republic, Slovakia and Poland. In Hungary is the perception quite different. Almost the same importance was given to all analysed risks in Hungary (market risk, economic risk, financial risk, personnel risk, security risk, legal risk, operational risk). The first research question was not confirmed.

The conclusion from the second research question also shows the difference in the concept of risk management in Hungary. It was found out that the person responsible for risks in the company is an owner of the company in the most cases. A risk manager specialized for this activity is still a rare situation in V4 countries (CR 2\%, SR 4\%, PL 4\%, HU 6\%). Hungary is a little bit further in risk management concept in comparison with other V4 countries. The statistically significant differences in the choice of the person responsible for risk management among V4 countries was proven. The second research question was confirmed.

The third research question analysed the size of the company as a significant factor for the frequency of discussion on the current risks in the company. The statistical differences were proven in SMEs in all V4 countries. It can be stated that in half of the micro-companies from V4 countries, the risks are not discussed almost at all. Bigger companies have a discussion on risks more often than smaller companies. $74 \%$ of medium companies in the Czech Republic discuss the risks monthly (in Slovakia $36 \%$, in Poland 25\%, in Hungary 40\%). The differences among responses in relation to the size of the company are clear in all V4 countries. The third research question was confirmed. The size of the company was proved as a statistically significant factor in the perception of a governmental financial support for SMEs in the Czech Republic. (Dobeš et al., 2017). Hernández-Cánovas and Koëter-Kant (2013) confirmed also the relation between the size of the company and debt maturity. They found that smaller companies are more influenced by the institutional environment in comparison with bigger companies.

The research has some limitations. The questionnaire was placed in all countries in the native languages, nevertheless, some misunderstanding can influence the results. The survey was conducted only in V4 countries; therefore, the results cannot be generalized. This research can be broadened to other countries within the EU to get a comprehensive knowledge about risk management in the EU. The result can be useful for professional public and for the organization which helps SMEs to overcome the obstacle in the business environment. 


\section{REFERENCES}

Belás, J., Vojtovič, S., \& Ključnikov, A. (2016). Microenterprises and Significant Risk Factors in Loan Process. Economics and Sociology, 9(1), 43-59. https://10.14254/2071-789X.2016/9-1/3

Belanová, K. (2014). Komparácia kvality podnikatel’ského prostredia v krajinách Vyšehradskej štvorky s osobitným akcentom na dostupnost’ finančných zdrojov. Biatec. 22(1). 12-17.

Cepel, M., Stasiukynas, A., Kotaskova, A., \& Dvorsky, J. (2018). BUSINESS ENVIRONMENT QUALITY INDEX IN THE SME SEGMENT. Journal of Competitiveness, 10 (2), 21-40. https://doi.org/10.7441/joc.2018.02.02

Christensen, B. J., Nielsen, M., \& Zhu, J. (2015), The impact of financial crisis on the risk-return tradeoff and the leverage effect, Economic Modelling, 49(1), 407-418. https://doi.org/ 10.1016/j.econmod.2015.03.006

Čunderlík, D., \& Rybárová, D. (2002). Podnikatelské riziko. Bratislava: Ekonóm.

Deloach, J. W. (2000), Enterprise-Wide Risk Management, London.

De Oliveira, U.R., Marins, F.A.S., Rocha, H.M., \& Salomon, V.A.P. (2017). The ISO 31000 standard in supply chain risk management. Journal of Cleaner Production, 151 (1),616-633. https://doi.org/10.1016/i.jclepro.2017.03.054

Dobeš K., Kot S., Kramoliš J., Sopková G. (2017). The Perception of Governmental Support in The Context of Competitiveness of SMEs in the Czech Republic. Journal of Competitiveness, 9 (3), 34-50. https://doi.org/10.7441/joc.2017.03.03

European Risk and Insurance Report (2016). Executive Summary of the FERMA, Risk Management Benchmarking survey. Retrieved November 11, 2018, from http://www.ferma. eu/riskmanagement/

Fetisovova, E., Hucova, E., Nagy, L., \& Vlachynsky, K. (2012). Aktualne problemy financii malych a strednych podnikov. Bratislava : Ekonom, 2012.

Gavurova, B., Packova, M., Misankova, M., \& Smrcka, L. (2017). Predictive Potential and Risks of Selected Bankruptcy Prediction Models in the Slovak Business Environment. Journal of Business Economics and Management, 18(6), 1156-1173. https://doi.org/10.3846/16111699.2017.1400461

Global Management Accountant - Global State of Enterprise Risk Oversight 2nd edition (2015). Retrieved October 18, 2018, from: http://erm.ncsu.edu/library/research-report/cgma-report-ontheglobal-state-of-enterprise-risk-oversight

Henderson, J., \& Weiler, S. (2010). Entrepreneurs and job growth: probing the boundaries of time and space, Economic Development Quarterly, 24(1), 23 - 32.

Hernández-Cánovas, G., Koëter-Kant, J. (2013). SME financing in Europe: Cross-country determinants of bank loan maturity. International Small Business Journal. 29(5), 489-507. https://doi.org/10.1177/0266242611402569

Hopkin, P. (2013). Risk Management. London.

Hudáková, M., Buganová, K., \& Lusková, M. (2014). Small and Medium-Sized Enterprises Business Risks in Slovakia. Paper presented at the Proceeding of the 18th World Multi-Conference on Systemics, Cybernetics and Informatics (WMSCI 2014), 240-245.

Hussain, J., Ismail K., \& Akhtar, Ch. S. (2015). Linking Entrepreneurial Orientation with Organizational Performance of Small and Medium Sized Enterprises: A Conceptual Approach. Asian Social Science, 11(7): 1-10. https://doi.org/10.5539/ass.v11n7p1

Ključnikov, A., \& Sobeková Majková, M. (2016). Impact of Gender in the Perception of Administrative Burdens among Young Entrepreneurs - Evidence from Slovakia. Journal of Competitiveness, 8(2), 17 - 30. https://doi.org/ 10.7441/joc.2016.02.02

Ključnikov, A. \& Belás, J. (2016). Approaches of Czech Entrepreneurs to Debt Financing and Management of Credit Risk. Equilibrium. Quarterly Journal of Economics and Economic Policy, 11(2), 343-365. https://doi.org/ 10.12775/EQUIL.2016.016

Ključnikov, A., \& Junger, R. (2013). Barriers for foreign direct investments in Belarus: Case of business logistics. In Proceedings of the Carpathian Logistics Congress.

Kot, S. (2018). Sustainable Supply Chain Management in Small and Medium Enterprises. Sustainability, 10 (4), art. no. 1143. 
Kozubíková, L., Belás, J., Bilan, Y., \& Bartoš, P. (2015). Personal characteristics of entrepreneurs in the context of perception and management of business risk in the SME segment. Economics \& Sociology, 8(1), 41-54. https://doi.org/ 10.14254/2071- 789X.2015/8-1/4

Kral, P., \& Kliestik, T. (2015), Estimation of the level of risk based on the selected theoretical probability distributions, Proceedings of the 10th International Scientific Conference on Financial Management of Firms and Financial Institutions Location, Ostrava, Czech Republic, 603-610.

Kramoliš, J. (2014). Product placement and product life cycle - czech SME study. Paper presented at the Proceedings of the 24th International Business Information Management Association Conference - Crafting Global Competitive Economies: 2020 Vision Strategic Planning and Smart Implementation, 1074-1084.

Krištofík, P. (2010). Poučenia z krízového vývoja. Finančný manažment. Retrieved November 11, 2018, from: http://www.financnymanazment.sk/2010-1/6-2010/Poucenia-z-krizoveho-vyvoja

Oláh, J., Zéman, Z., Balogh, I., \& Popp, J. (2018). Future challenges and areas of development for supply chain management. LogForum, 14 (1), 127-138. https://doi.org/10.17270/J.LOG.2018.238

Paulík, J., Kombo, F., \& Ključnikov, A. (2015). CSR as a driver of satisfaction and loyalty in commercial banks in the Czech Republic. Journal of International Studies, 8(3), 111-126. https://doi.org/10.14254/2071-8330.2015/8-3/9

Popp, J., Oláh, J., Machova, V., \& Jachowicz, A. (2018). Private equity market of the Visegrad group. Ekonomicko-manazerske spektrum, 12 (1), 1-15. https://doi.org/10.26552/ems.2018.1.1-15

Report on the Current State of Enterprise Risk Oversight: Update on Trends and Opportunities (2015). Retrieved October 17, 2018, from http://erm.ncsu.edu/library/article/current- state-erm-2015

Taraba, P., Heinzová, R., Pitrová, K., Hart, M., \& Trojan, J. (2015). Project risks in enterprises in the Czech Republic. Paper presented at the Proceedings of the 25th International Business Information Management Association Conference - Innovation Vision 2020: From Regional Development Sustainability to Global Economic Growth, IBIMA 2015, 814-821.

Urbancová H., \& Hudáková M. (2015), Employee Development in Small and Medium Enterprise in the Light of Demographic Evolution, Acta Universitatis Agriculturae et Silviculturae Mendelianae Brunensis, 63(3), 1043-1050. https://doi.org/10.11118/actaun201563031043

Varcholová, T., \& Dubovická, L. (2008). Nový manažment riq̣ika. Bratislava: Iura Edition.

Vodak, J., Soviar, J., \& Lendel, V. (2014). Cooperation management in Slovak enterprises. Procedia Social and Behavioral Sciences. Proceedings of 2 nd world conference on business, economics and management, Istanbul, Turkey, 1147-1151. https://doi.org/10.1016/j.sbspro.2013.12.602 